\title{
Tracheal Glomus Tumor: A Multidisciplinary Approach to Management
}

\author{
Lama Sakr MD, Ramanathan Palaniappan MD, Marie-José Payan MD, \\ Christophe Doddoli MD PhD, and Hervé Dutau MD
}

\begin{abstract}
A 66-year-old man presented with acute respiratory distress due to a tracheal tumor involving the posterior wall of the upper trachea, with nearly complete airway obstruction. Partial debulking of the tumor's endoluminal component, via rigid bronchoscopy and yttrium-aluminum-perovskite laser, allowed timely and effective airway restoration. The diagnosis was benign tracheal glomus tumor. Two weeks later, elective tracheal sleeve resection with end-to-end anastomosis allowed complete resection of the lesion. No tumor recurrence was found at 21-month follow-up. We describe the multidisciplinary management of this extremely rare tracheal tumor, and review its features. Key words: glomus tumor; trachea; rigid bronchoscopy; yttrium-aluminum-perovskite laser; yttrium-aluminum-perovskite laser; sleeve resection. [Respir Care 2011;56(3):342-346. (C) 2011 Daedalus Enterprises]
\end{abstract}

\section{Introduction}

Glomus tumors are neoplasms arising from the neuromyoarterial elements of glomus bodies ${ }^{1,2}$ which are specialized arteriovenous anatomoses surrounded by modified smoothmuscle cells or glomus cells. They are most often found in the dermis and subcutaneous tissues, ${ }^{3}$ and contribute to blood flow regulation and temperature control on the skin surface. They are sparse or even absent in visceral organs, making extracutaneous presentation a rare finding.

\section{Case Report}

A 66-year-old man was referred to our institution for management of a tracheal lesion causing acute respiratory distress and stridor. Ten days earlier he had sought med-

Lama Sakr MD, Ramanathan Palaniappan MD, and Hervé Dutau MD are affiliated with the Thoracic Endoscopy Unit; Marie-José Payan MD is affiliated with the Department of Pathology; and Christophe Doddoli MD $\mathrm{PhD}$ is affiliated with the Thoracic Surgery Unit, Assistance Publique Hôpitaux de Marseille, Université de la Méditerrannée, Marseille, France.

The authors have disclosed no conflicts of interest.

Correspondence: Hervé Dutau MD, Thoracic Endoscopy Unit, Hôpital Sainte-Marguerite, 270, Boulevard de Sainte-Marguerite, 13274 Marseille, Cedex 09, France. E-mail. hdutau@ap-hm.fr.

DOI: $10.4187 /$ respcare.00761 ical attention for progressive dyspnea and worsening dry cough over the past 2 months. His medical history was notable for 30 pack-years cigarette smoking, chronic atrial fibrillation, and hypertension. Physical examination at that time revealed a comfortable patient at rest, without stridor or audible breathing, but with dyspnea on mild exertion. His lungs were clear to auscultation, and heart examination was normal. A chest radiograph was reported as normal (Fig. 1). Because of his smoking history, he underwent thoracic computed tomography, which revealed an endoluminal, exophytic mass $(1.2 \mathrm{~cm}$ anteroposteriorly, $0.8 \mathrm{~cm}$ wide, $2.0 \mathrm{~cm}$ craniocaudally) involving the posterior wall of the cervical trachea. We suspected transmural extension of the lesion (Fig. 2). There was no lymphadenopathy, parenchymal lung lesion, pleural abnormality, or evidence of metastasis. Flexible bronchoscopy showed a sessile lesion in the upper trachea, occluding approximately $75 \%$ of the airway lumen. Surgery was scheduled for the next week, but due to acute worsening of respiratory symptoms over the following days, prompt bronchoscopic management was deemed necessary.

With the patient under general anesthesia we inserted a 13.2-mm outer-diameter rigid tracheoscope (Dumon-Efer, Efer, La Ciotat, France). A solid mass with a sessile base and 2 polypoid lesions at its luminal surface seemed to arise from the posterior wall of the upper third of the trachea, and it had intraluminal and transmural components. The intraluminal component occluded the airway 


\section{Tracheal Glomus Tumor: A Multidisciplinary Approach to Management}

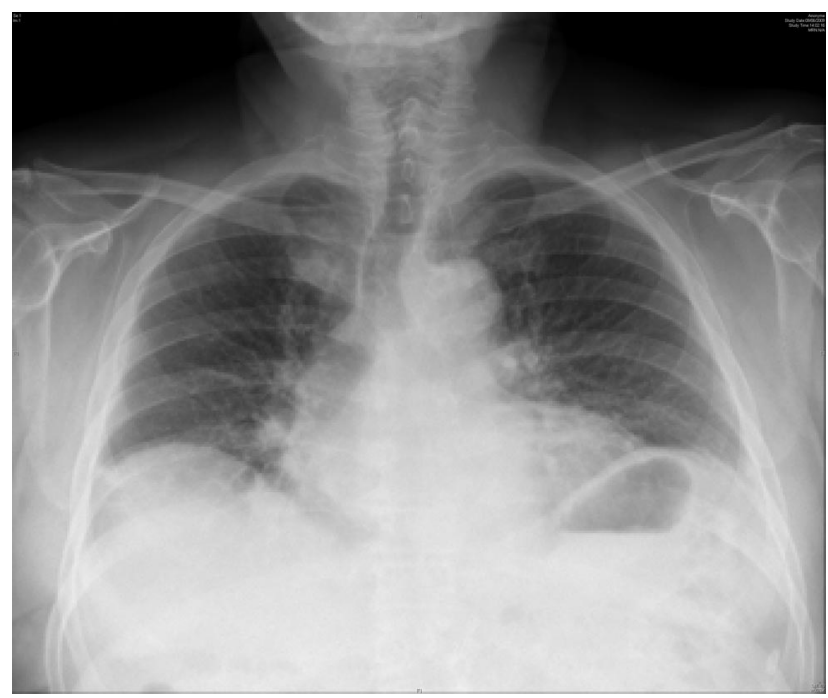

Fig. 1. Initial chest radiograph, reported as normal.

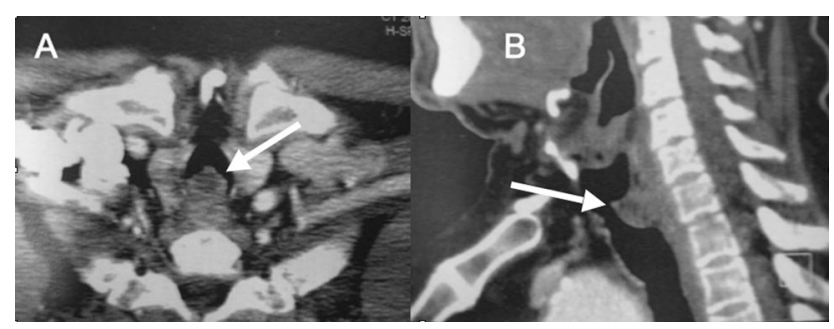

Fig. 2. Computed tomograms of the tracheal glomus tumor. A: Cross-sectional view. B: Sagittal view. There is an endoluminal exophytic mass arising from the posterior wall of the cervical trachea, with endoluminal and transmural components.

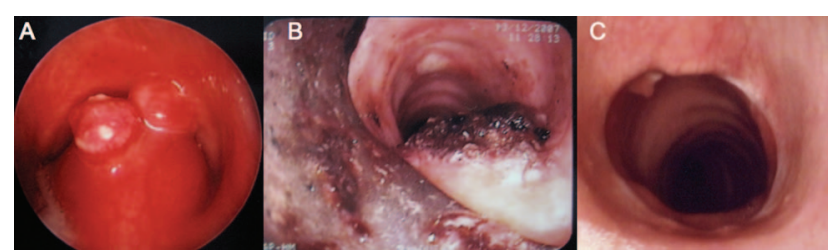

Fig. 3. A: Tracheal glomus tumor with a sessile base and 2 polypoid lesions at its luminal surface, involving the posterior tracheal wall. The endoluminal and transmural components are visible. Anterior bulging of the posterior wall was caused by transmural extension of the lesion. B: Tracheal lumen following bronchoscopic resection and application of yttrium-aluminum-perovskite laser over the excised base. C: 18 months after surgical resection there is complete airway patency; a small granuloma over the left anterior wall was benign.

almost completely, yielding abundant tracheal secretions. The transmural extension caused anterior bulging of the posterior wall, further narrowing the airway lumen (Fig. 3A). We excised the endoluminal component with the beveled tip of the tracheoscope, pulled the lesion to the distal end of the tracheoscope with a suction catheter, then withdrew the tracheoscope and resected part of the lesion.

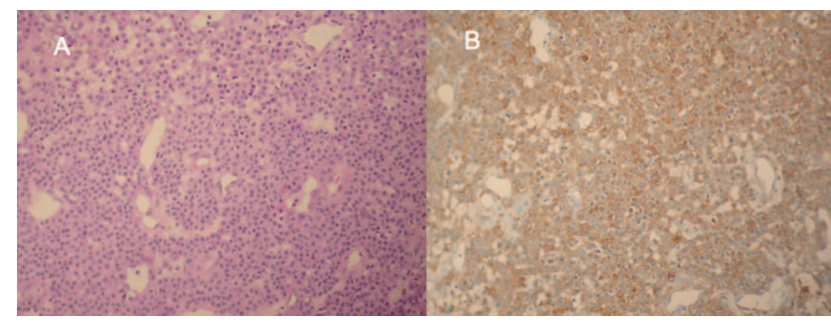

Fig. 4. Biopsy of the tracheal tumor shows $(A)$ round cells with regular nuclei, forming small nests around surrounding dilated capillaries (hematoxylin-phloxine-saffron stain, magnification 100), and (B) on immunohistochemical evaluation, tumor cells stained for smooth-muscle actin (magnification 100).

We then re-inserted the tracheoscope and found mild bleeding and some residual tissue at the excised base. We then used yttrium-aluminum-perovskite laser $(1.34 \mu \mathrm{m}$ wavelength, $4 \mathrm{~mm}$ beam diameter) (ElEn, Florence, Italy) to achieve hemostasis and vaporize the remaining lesion tissue (Fig. 3B). Following the procedure we scheduled a surgical consultation for further management.

Histology revealed round epithelioid cells with eosinophilic cytoplasms and regular nuclei, forming small nests and surrounding dilated capillaries (Fig. 4A). On immunohistochemical evaluation the cells stained for smoothmuscle actin and vimentin, but not for endothelial (CD31/ CD34), epithelial (AE1/AE3), or neuroendocrine markers (Fig. 4B). Based on morphological and immunohistochemical properties, the diagnosis was glomus tumor.

Two weeks following the endoscopic excision the patient underwent sleeve resection of the first 2 tracheal rings and end-to-end anastomosis. Pathology showed complete tumor resection with clear microscopic margins.

\section{Discussion}

Glomus tumors were first described by Masson in $1924 .{ }^{4}$ They are uncommon neoplasms, constituting less than $2 \%$ of all soft-tissue tumors. ${ }^{5}$ They can be solitary or multicentric, and are most commonly found in the subungual area. ${ }^{1}$ Unusual sites have included muscle, tendons, ligaments, periosteum, and visceral organs such as the stomach, vagina, penis, mediastinum, heart, lung, and trachea. ${ }^{6}$

Glomus tumors of the trachea are rare. The first case was reported in $1978 .^{7}$ To our knowledge, 19 cases of tracheal glomus tumor have been described so far, most commonly arising from the posterior wall of the lower two thirds of the trachea, where mucus glands and vessels are numerous (Table 1). ${ }^{8-25}$ Endobronchial and lung-parenchyma glomus tumors have been also reported. 19,21,26

Glomus tumor of the trachea is more common in males (male-to-female ratio 2:1 to 7:1), and at a mean age of 45 years. However, glomus tumor was recently reported in a 10 -year-old girl. ${ }^{24}$ Common presenting symptoms in- 


\section{Tracheal Glomus Tumor: A Multidisciplinary Approach to Management}

Table 1. Case Reports of Tracheal Glomus Tumor

\begin{tabular}{|c|c|c|c|c|c|c|c|c|c|c|}
\hline First Author & Year & Age & Sex & Symptoms & $\begin{array}{l}\text { Size } \\
(\mathrm{cm})\end{array}$ & $\begin{array}{l}\text { Tracheal } \\
\text { Location }\end{array}$ & Extension & $\begin{array}{l}\text { Time Between } \\
\text { Symptom } \\
\text { Onset } \\
\text { and Treatment }\end{array}$ & Treatment & Outcome \\
\hline Hussarek $^{8}$ & 1950 & 43 & $\mathrm{~F}$ & Dyspnea & "Bean-sized" & Subglottic & Endoluminal & Not stated & $\begin{array}{l}\text { Tracheal } \\
\text { resection }\end{array}$ & Not stated \\
\hline Fabich $^{9}$ & 1980 & 63 & M & Cough & $2.5 \times 2 \times 1$ & Lower third & Endoluminal & 2 years & $\begin{array}{l}\text { Tracheal } \\
\text { resection }\end{array}$ & $\begin{array}{l}\text { Died of } \\
\text { complications, } \\
\text { postop day } 10\end{array}$ \\
\hline Heard $^{10}$ & 1982 & 50 & M & $\begin{array}{l}\text { Asthma-like } \\
\text { symptoms }\end{array}$ & $2.5 \times 1.5 \times 1.0$ & Lower third & Extratracheal & Not stated & $\begin{array}{l}\text { Tracheal } \\
\text { resection }\end{array}$ & $\begin{array}{l}\text { Sepsis, died post- } \\
\quad \text { op day } 15\end{array}$ \\
\hline Ito $^{11}$ & 1988 & 51 & M & $\begin{array}{l}\text { Respiratory } \\
\text { infections, } \\
\text { hemoptysis }\end{array}$ & $1.5 \times 1.2 \times 1.0$ & Upper third & Endoluminal & 9 months & $\begin{array}{l}\text { Tracheal } \\
\text { resection }\end{array}$ & $\begin{array}{l}\text { No recurrence at } \\
2 \text { years }\end{array}$ \\
\hline $\mathrm{Kim}^{12}$ & 1989 & 54 & $\mathrm{~F}$ & $\begin{array}{l}\text { Cough, } \\
\text { dyspnea, } \\
\text { hemoptysis }\end{array}$ & $1.5 \times 1.2$ & Mid-trachea & Endoluminal & $\begin{array}{l}3 \text { years } \\
\text { (cough) }\end{array}$ & $\begin{array}{l}\text { Tracheal } \\
\text { resection }\end{array}$ & $\begin{array}{l}\text { No recurrence at } \\
13 \text { months }\end{array}$ \\
\hline $\operatorname{Shin}^{13}$ & 1990 & 47 & $\mathrm{~F}$ & $\begin{array}{l}\text { Intermittent } \\
\text { cough } \\
\text { and } \\
\text { hemoptysis }\end{array}$ & $1.5 \times 1.0 \times 1.0$ & Lower third & Endoluminal & 3 years & $\begin{array}{l}\text { Tracheal } \\
\text { resection }\end{array}$ & Not stated \\
\hline Garcia-Prats $^{14}$ & 1991 & 58 & M & $\begin{array}{l}\text { Dyspnea, } \\
\text { cough, } \\
\text { occasional } \\
\text { hemoptysis }\end{array}$ & $2.5 \times 1.8$ & Mid-trachea & Extratracheal & Many years & $\begin{array}{l}\text { Tracheal } \\
\text { resection }\end{array}$ & $\begin{array}{l}\text { No recurrence at } \\
8 \text { months }\end{array}$ \\
\hline Haraguchi $^{15}$ & 1991 & 61 & M & Asymptomatic & 1.2 & Mid-trachea & Endoluminal & Asymptomatic & $\begin{array}{l}\text { Tracheal } \\
\text { resection }\end{array}$ & Not stated \\
\hline Arapantoni ${ }^{16}$ & 1995 & 65 & M & $\begin{array}{l}\text { Dyspnea, } \\
\text { hemoptysis }\end{array}$ & $4.5 \times 3$ & Lower third & Endoluminal & $\begin{array}{l}3 \text { months } \\
\text { (dyspnea), } \\
3 \text { days } \\
\text { (hemoptysis) }\end{array}$ & $\begin{array}{l}\text { Endoscopic } \\
\text { resection and } \\
\text { Nd-YAG }\end{array}$ & $\begin{array}{l}\text { No recurrence at } \\
1 \text { year }\end{array}$ \\
\hline Koskinen $^{17}$ & 1998 & 66 & M & Asymptomatic & & Lower third & Extratracheal & Not stated & $\begin{array}{l}\text { Endoscopic } \\
\text { resection, } \\
\text { Nd-YAG, } \\
\text { and external } \\
\text { radiotherapy }\end{array}$ & Not stated \\
\hline Watanabe $^{18}$ & 1998 & 43 & M & Hoarseness & $2.0 \times 1.6 \times 1.4$ & Lower third & Endoluminal & Not stated & $\begin{array}{l}\text { Tracheal } \\
\quad \text { resection }\end{array}$ & $\begin{array}{l}\text { No recurrence at } \\
20 \text { months }\end{array}$ \\
\hline Menaissy ${ }^{19}$ & 2000 & 34 & M & Hemoptysis & $2.4 \times 2.1 \times 1.6$ & Mid-trachea & Endoluminal & 2 months & $\begin{array}{l}\text { Tracheal } \\
\text { resection }\end{array}$ & $\begin{array}{l}\text { No recurrence at } \\
4 \text { months }\end{array}$ \\
\hline Lange $^{20}$ & 2000 & 20 & M & $\begin{array}{r}\text { Asthma-like } \\
\text { symptoms }\end{array}$ & $1.5 \times 1.0 \times 0.4$ & $\begin{array}{l}\text { Left main } \\
\text { bronchus }\end{array}$ & Endoluminal & Not stated & $\begin{array}{l}\text { Bronchial } \\
\text { sleeve } \\
\text { resection }\end{array}$ & $\begin{array}{l}\text { No recurrence at } \\
9 \text { months }\end{array}$ \\
\hline Gowan $^{21}$ & 2001 & 73 & M & $\begin{array}{l}\text { Cough, } \\
\text { hemoptysis, } \\
\text { dyspnea, } \\
\text { chest } \\
\text { pain }\end{array}$ & $1.6 \times 0.3 \times 0.6$ & Mid-trachea & Endoluminal & 5 weeks & $\begin{array}{l}\text { Tracheal } \\
\text { resection }\end{array}$ & $\begin{array}{l}\text { No recurrence at } \\
6 \text { years }\end{array}$ \\
\hline Chien $^{22}$ & 2003 & 50 & $\mathrm{~F}$ & $\begin{array}{l}\text { Cough, } \\
\text { dyspnea, } \\
\text { hemoptysis }\end{array}$ & $2.5 \times 2.5 \times 2$ & Lower third & Transmural & $\begin{array}{l}8 \text { years } \\
\text { (cough and } \\
\text { dyspnea), } \\
1 \text { day } \\
\text { (hemoptysis) }\end{array}$ & $\begin{array}{l}\text { Tracheal } \\
\text { resection }\end{array}$ & $\begin{array}{l}\text { No recurrence at } \\
1 \text { years }\end{array}$ \\
\hline Nadrous $^{23}$ & 2004 & 39 & M & $\begin{array}{l}\text { Intermittent } \\
\text { hemoptysis }\end{array}$ & $2.0 \times 1.5 \times 1.5$ & Upper third & Extratracheal & 30 months & $\begin{array}{l}\text { Tracheal } \\
\quad \text { resection }\end{array}$ & $\begin{array}{l}\text { No recurrence at } \\
3 \text { months }\end{array}$ \\
\hline Haver $^{24}$ & 2008 & 10 & $\mathrm{~F}$ & Dyspnea & $1.8 \times 1.3 \times 1.3$ & $\begin{array}{l}\text { Middle to } \\
\text { lower } \\
\text { trachea }\end{array}$ & Extratracheal & 3 weeks & $\begin{array}{l}\text { Tracheal } \\
\quad \text { resection }\end{array}$ & $\begin{array}{l}\text { No recurrence at } \\
2 \text { years }\end{array}$ \\
\hline Colaut $^{25}$ & 2008 & 70 & M & Dyspnea & $2 \times 1 \times 1$ & Mid-trachea & Endoluminal & 2 months & $\begin{array}{l}\text { Endoscopic } \\
\text { resection and } \\
\text { Nd-YAG }\end{array}$ & $\begin{array}{l}\text { No recurrence at } \\
2 \text { years }\end{array}$ \\
\hline
\end{tabular}




\section{Tracheal Glomus Tumor: A Multidisciplinary Approach to Management}

clude hemoptysis, dyspnea, and cough. Less frequently, chest pain, stridor, and hoarseness have been described (see Table 1). ${ }^{23,24}$ Tumor size has ranged from $1.2 \mathrm{~cm}$ to $4.5 \mathrm{~cm} .{ }^{23}$ Lag time between symptom onset and diagnosis has been widely variable. The vast majority of cases were surgically resected, without evidence of recurrence at follow-up ranging from 3 months to 6 years. ${ }^{25}$ Definite endoscopic resection with laser-assisted mechanical debulking with a rigid bronchoscope has been described in 3 patients, with successful outcomes. ${ }^{16,17,25}$ No tumor recurrence was reported in 2 of those patients at follow-ups at 12 months and 24 months. ${ }^{16,25}$ No follow-up data were reported for the third subject. ${ }^{17}$ It is noteworthy, however, that in all 3 cases, the tumor was confined to the airway lumen, without evidence of extratracheal extension. Transmural or extratracheal extension of a glomus tumor has been described in only 5 patients, ${ }^{10,14,17,23,24} 4$ of whom were managed with tracheal resection. ${ }^{10,14,23,24}$ No follow-up data were available for the patient who was treated with neodymium-yttrium-aluminum-garnet laser-assisted resection and external beam radiotherapy. ${ }^{17}$ Three of the 4 surgery patients had no recurrence at follow-up ranging from 3 months to 2 years ${ }^{14,23,24}$; the fourth patient died of sepsis and multi-organ failure on the 15 th postoperative day. ${ }^{10}$

On histologic evaluation, glomus tumor cells are mediumsized, have round regular nuclei and eosinophilic cytoplasm, and are arranged in sheets that form collars around capillarysize vessels. They stain for smooth-muscle actin and vimentin, but not for cytokeratin, chromogranin, or neuroendocrine markers. ${ }^{1}$ Ultrastructurally, pinocytotic vesicles and myofibrils with dense bodies are seen within the tumor cells.

Glomus tumors are most often benign, although atypical and malignant features have been described in occasional cases. ${ }^{27}$ This has prompted the reclassification of glomus tumors on the basis of their biologic activity. The World Health Organization's classification divides glomus tumors into benign glomus tumors, glomus tumors of uncertain malignant potential, and malignant glomus tumors. ${ }^{28}$ Over 95\% are benign. ${ }^{27}$ Glomus tumors are further classified into 3 categories, with regard to the proportions of glomus cells, vessels, and smooth-muscle components: the Glomus tumor proper type, with the round glomus cells representing the largest component; the glomangioma type, where vessels are predominantly present; and glomangiomyoma, where spindle cells are the predominant cell type. ${ }^{29,30}$ An oncocytic type, where the tumor cells are characterized ultrastructurally by numerous closely packed round or ovoid mitochondria, has also been described. ${ }^{13}$ The histologic criteria of malignancy in glomus tumors are deep location, size $>2 \mathrm{~cm}$, presence of atypical mitotic figures, or a combination of moderate to high nuclear grade and $\geq 5$ mitotic figures per 50 high-power field. Although no glomus tumors of the trachea have been found to be malignant so far, tumor extension within the tracheal wall has been described in only 6 cases, including our patient. 23,24
The main differential diagnoses of tracheal glomus tumor are carcinoid tumor and hemangiopericytoma. ${ }^{1,29} \mathrm{Car}-$ cinoid tumor has a less prominent vascular pattern, stains positively for neuroendocrine markers (namely chromogranin and synaptophysin), does not react with antibodies to smooth-muscle actin, and shows intracytoplasmic densecore granules under an electron microscope. On the other hand, a hemangiopericytoma consists of spindle-shaped cells with elongated nuclei, the vascular channels display a "staghorn-like" pattern, and the cells stain positive for vimentin with or without CD34 and CD57. Smooth-muscle differentiation is infrequent.

Sleeve resection with primary reconstruction of the trachea is the treatment of choice for tracheal glomus tumor. ${ }^{31}$ Complete surgical resection is curative, does not require adjuvant treatments, and has an excellent prognosis. Endoscopic intervention alone may be indicated if: the lesion is strictly confined to the airway lumen without extension into the airway wall; histology confirms the tumor is benign; or the patient is not fit or willing to undergo surgical resection. Interventional bronchoscopy is definitely a first-line treatment in urgent situations where immediate restoration of airway patency is required. Endoscopic resection may therefore be a definitive treatment or a temporary measure allowing patient stabilization before surgery. Bronchoscopic interventional techniques include laser photocoagulation, electrocautery, and mechanical debulking with the beveled edge of a rigid scope.

The optimal anesthetic approach in patients with central airway obstruction is debatable. Large-airway obstruction can delay achieving equilibrium between the inspired concentration and the alveolar concentration of inhaled anesthetic, ${ }^{32}$ so intravenous anesthetic induction may be faster. However, if induction is too fast, the airway may be lost. It is noteworthy, however, that airway loss has occurred with both intravenous and inhaled anesthesia induction. ${ }^{33}$ On the other hand, inhaled induction may cause airway irritation, inducing cough and increased intrathoracic pressure, therefore exacerbating large-airway obstruction. ${ }^{32}$ Despite the theoretical disadvantages, inhaled agents such as halothane and sevoflurane have been widely used in similar settings, without major differences in outcome..$^{33}$ In our patient the anesthetic protocol consisted of intravenous target-controlled infusion of propofol with opioid supplementation, with a low concentration of remifentanil to ensure spontaneous ventilation throughout the procedure. ${ }^{34}$ Patients with large-airway obstruction may not be able to endure the supine position during anesthetic induction, so the induction is carried out with the patient semirecumbent. Once the patient loses consciousness, he is positioned supine and the rigid bronchoscope is introduced.

Tracheal glomus tumor with both endoluminal and transmural components is extremely rare: only 6 cases, including our patient, have been reported.10,14,17,23,24 Since our patient had tumor invasion of the tracheal wall, we be- 


\section{Tracheal Glomus Tumor: A Multidisciplinary Approach to Management}

lieved that surgical resection was the only definitive treatment. Although data are scant, previous reports have described successful surgical management of glomus tumors with extratracheal extension. No recurrence was observed at follow-ups ranging from 3 months to 2 years. ${ }^{14,23,24}$ On the other hand, the only case report describing endoscopic resection of a glomus tumor that involved the tracheal wall did not present any follow-up data. ${ }^{17}$ In addition, tumor regrowth has been described following a large excisional biopsy prior to definitive treatment, ${ }^{24}$ which suggests that tumor recurrence is possible with incomplete resection. Therefore, when complete tumor excision is not endoscopically feasible, as when the tumor invades the tracheal wall, surgical management is the definitive strategy. If our patient had been a poor surgical candidate, endoscopic treatment alone would have been suitable, allowing tumor debulking and symptom palliation, but close clinical and bronchoscopic follow-up would have been required for early diagnosis and management of tumor recurrence. Although not curative in this scenario, initial bronchoscopic intervention played a pivotal role, as it allowed timely and effective airway restoration in a severely symptomatic patient and provided diagnostic information before surgery. Our patient's prognosis is excellent, as there has been no evidence of tumor recurrence over a 21-month follow-up period (Fig. 3C).

\section{REFERENCES}

1. Gaertner EM, Steinberg DM, Huber M, Hayashi T, Tsuda N, Askin FB, et al. Pulmonary and mediastinal glomus tumors - report of five cases including a pulmonary glomangiosarcoma: a clinicopathologic study with literature review Am J Surg Pathol 2000;24(8): 1105-1114.

2. Murad T, Von Hamm E, Murthy MS. Ultrastructure of a hemangiopericytoma and a glomus tumor. Cancer 1968;22(6):1234-1249.

3. Enzinger FM, Weiss SW. Soft tissue tumors. St Louis: Mosby; 1995; 701-733.

4. Masson P. Le glomus neuromyoarterial des regions táctiles et ses tumeurs. Lyon Chir 1924;21:257-280. Article in French.

5. Weiss SW, Goldblum JR. Perivascular tumors. In: Enzinger FM, Weiss SW, editors. Soft tissue tumors. St Louis: Mosby; 2001:985-1001.

6. Filice ME, Lucchi M, Loggini B, Mussi A, Fontanini G. Glomus tumor of the lung: case report and literature review. Pathologica 2008;100(1):25-30.

7. Tang CK, Toker C, Forls NP, Trump BF. Glomangioma of the lung. Am J Surg Pathol 1978;2(1):103-109.

8. Hussarek M, Rieder W. Glomustumor der luftrohve. Krebsarzt 1950; 5:208-212.

9. Fabich DR, Hafez GR. Glomangioma of the trachea. Cancer 1980; 45(9):2337-2341.

10. Heard BE, Dewar A, Firmin RK, Lennox SC. One very rare and one new tracheal tumor found by electron microscopy: glomus tumor and acinic cell tumor resembling carcinoid tumors by light microscopy. Thorax 1982;37(2):97-103.

11. Ito $\mathrm{H}$, Motohiro $\mathrm{K}$, Nomura S, Tahara E. Glomus tumor of the trachea: immunohistochemical and electron microscopic studies. Pathol Res Pract 1988;183(6):778-784.

12. Kim YJ, Kim JH, Suh JS, Ham EK, Suh KP. Glomus tumor of the trachea: report of a case with ultrastructural observation. Cancer 1989;64(4):881-886.
13. Shin DH, Park SS, Lee JH, Park MH, Lee JD. Oncocytic glomus tumor of the trachea. Chest 1990;98(4):1021-1023.

14. García-Prats MD, Sotelo-Rodríguez MT, Ballestín C, MartínezGonzález MA, Roca R, Alfaro J, De Miguel E. Glomus tumor of the trachea: report of a case with microscopic, ultrastructural and immunohistochemical examination and review of the literature. Histopathology 1991;19(5):459-464.

15. Haraguchi S, Yamamoto M, Nishimura H. A glomus tumor of the trachea: a case report. Nippon Kyobu Geka Gakkai Zasshi 1991; 39(2):214-218.

16. Arapantoni-Dadioti P, Panayiotides J, Fatsis M, Antypas G. Tracheal glomus tumor. Respiration 1995;6(3)2:160-162.

17. Koskinen SK, Niemi PT, Ekfors TO, Sipilä J, Valavaara R, Dean PB. Glomus tumor of the trachea. Eur J Radiol 1998;8(3):364-366.

18. Watanabe M, Takagi K, Ono K, et al. Successful resection of a glomus tumor arising from the lower trachea: report of a case. Surg Today 1998;28(3):332-334.

19. Menaissy YM, Gal AA, Mansour KA. Glomus tumor of the trachea. Ann Thorac Surg 2000;70(1):295-297.

20. Lange TH, Magee MJ, Boley TM, Bell SW, Hazelrigg SR. Tracheobronchial glomus tumor. Ann Thorac Surg 2000;70(1):292-295.

21. Gowan RT, Shanji FM, Perkins DG, Maziak DE. Glomus tumor of the trachea. Ann Thorac Surg 2001;72(2):598-600.

22. Chien ST, Lee TM, Hsu JY, Wang JS, Tseng HH. Glomus tumor of the trachea. J Chin Med Assoc 2003;66(9):551-554.

23. Nadrous HF, Allen MS, Bortholmai BJ, Aughenbaugh GL, Lewis JT, Jett JR. Glomus tumor of the trachea: value of multidetector computed tomographic virtual bronchoscopy. Mayo Clin Proc 2004; 79(2):237-240.

24. Haver KE, Hartnick CJ, Ryan DP, Shailam R, Mark EJ. Case 102008: a 10-year-old girl with dyspnea on exertion. N Engl J Med 2008;358(13):1382-1390.

25. Colaut F, Taniolo L, Scapinello A, Pozzobon M. Tracheal glomus tumor successfully resected with rigid bronchoscopy: a case report. J Thorac Oncol 2008;3(9):1065-1067.

26. De Cocker J, Messaoudi N, Waelput W, Van Schil PE. Intrapulmonary glomus tumor in a young woman. Interact Cardiovasc Thorac Surg 2008;7(6):1191-1193.

27. Folpe AL, Fanburg-Smith JC, Miettienen M, Weiss SW. Atypical and malignant glomus tumors: Analysis of 52 cases with a proposal for the reclassification of glomus tumors. Am J Surg Pathol 2001; 25(1):1-12.

28. Folpe AL. Glomus tumours. In: Fletcher CD, Unni KK, Mertens F, editors. World Health Organization classification of tumors: pathology and genetics of tumors of soft tissue and bone. Lyon, France: IARC Press; 2002:136-137.

29. Alt B, Huffer WE, Belchis DA. A Vascular lesion with smooth muscle differentiation presenting as a coin lesion in the lung: glomus tumor versus hemangiopericytoma. Am J Clin Pathol 1983;80(5): 765-771.

30. Hiruta N, Kameda N, Tokudome T, Tsuchiya K, Nonaka H, Hatori $\mathrm{T}$, et al. Malignant glomus tumor: a case report and review of the literature. Am J Surg Pathol 1997;21(9):1096-1103.

31. Grillo HC. Surgery of the trachea and bronchi. Hamilton, ON, Canada: B.C. Decker; 2004.

32. McMahon CC, Rainey L, Fulton B, Conacher ID. Central airway compression: anaesthetic and intensive care consequences. Anaesthesia 1997;52(2):150-168

33. Ernst A, Feller-Kopman D, Becker HD, Mehta AC. Central airway obstruction. Am J Respir Crit Care Med 2004;169(12):1278-1297.

34. Passot S, Servin F, Allary R, Pascal J, Prades JM, Auboyer C, Molliex S. Target- controlled versus manually controlled infusion of propofol for direct laryngoscopy and bronchoscopy. Anesth Analg 2002;94(5):1212-1216. 